\title{
Perioperative data for retroperitoneal lymph node dissection in patients with nonseminomatous testicular cancer: Retrospective analysis from a single institution
}

\author{
Eduardo de Paula Miranda, Daniel Kanda Abe, Adriano J oão Nesrallah, Marcos F Dall'Oglio, \\ Alexandre Crippa, Miguel Srougi \\ Division of Urology of the University of São Paulo Medical School, and Department of Uro-Oncology of the São Paulo State \\ Cancer Institute, São Paulo/SP-Brazil
}

Correspondence: Marcos F Dall'Oglio. Address: Rua Barata Ribeiro, 398 - $5^{\circ}$ andar - CEP 01308-000 - São Paulo - SP -Brasil. Email: marcosdallogliouro@terra.com.br

Received: November 14, 2012 Accepted: October 8, 2013

Online Published: October 17, 2013

DOI : $10.5430 /$ jst.v3n6p5

URL: http://dx.doi.org/10.5430/jst.v3n6p5

\section{Abstract}

Background: The aim of this study is to evaluate perioperative morbidity of retroperitoneal lymph node dissection (RPLND) in patients with germ cell tumors in a reference center for cancer in Brazil.

Methods: We performed a retrospective analysis of all patients from our computerized database from all patients who underwent RPLND. Intraoperative variables such as surgical time, blood loss, length of hospital stay, number of blood units required and associated procedures were evaluated.

Results: A total of 28 cases were reviewed. The mean age was 27.8 years. The average operating time was 308 minutes. The blood loss averaged $865 \mathrm{ml}$. The average hospital stay was 6 days. As to the magnitude of the dissection, in 16 (57.1\%) cases a nerve-sparing technique was applied. 39.2\% of patients experienced at least one associated procedure.

Conclusions: Retroperitoneal lymph node dissection is still a high morbidity procedure but necessary to obtain oncologic control in high-risk cases, even in those with metastatic disease.

\section{Key words}

Neoplasms, Testicular cancer, Retroperitoneal lymph node dissection, Morbidity

\section{I ntroduction}

Although testicular tumors are relatively rare, they still represent the most frequent neoplasm in men between 15 and 35 years of age ${ }^{[1,2]}$. Such tumors account for $1 \%$ to $1.5 \%$ of all cancers in men and the annual incidence is about 4.6 cases per 100,000 men in developed countries ${ }^{[3,4]}$, while this estimative is approximately 2.2 new cases per 100,000 inhabitants in Brazil ${ }^{[5]}$. 
Recently, testicular cancer serves as a paradigm for the multimodal treatment of malignancies. It is not only one of the most chemosensitive tumors, but also responds well to surgical intervention. The appropriate integration of chemotherapy and surgery for the management of testis cancer has resulted in overall survival rates greater than $90 \%{ }^{[6-8]}$.

Retroperitoneal lymph node dissection (RPLND) plays an important role in the management of patients with germ cell tumors ${ }^{[6-11]}$. Patients at higher stages with metastatic disease should receive chemotherapy for systemic control first, and for residual retroperitoneal masses, a post chemotherapy procedure (PC-RPLND) is the treatment of choice, although it has been shown that at least one third of those patients have necrotic tissue instead of tumor in final pathological analysis ${ }^{[6,12-15]}$. The purpose is report the experience of an university hospital in Brazil, assessing the perioperative morbidity of RPLND in patients with germ cell tumors.

\section{Patients and methods}

We performed a retrospective analysis of all patients from our computerized database who were diagnosed with nonseminomatous disease and underwent PC-RPLND between January 2005 and September 2011. All patients were identified and perioperative data were obtained. Patients were submitted to PC-RPLND after having undergone 3 to 4 cycles of primary chemotherapy with bleomycin, toposide and cisplatin.

Intraoperative surgical variables were analyzed: surgical time, blood loss, length of hospital, number of blood units required and complications rates. Variables regarding the technique itself were also assessed, including cavity access (median laparotomy, S incision or laparoscopy) and the magnitude of dissection (nerve-sparing or bilateral node dissection).

This study was previously approved by the Committee on Ethics in Research of our institution. Analyses were performed using the Statistical Package for Social Sciences (SPSS, version 12.0, Chicago, Ill).

\section{Results and discussion}

A total of 37 patients were submitted to RPLND, from which 6 were excluded for incomplete data, 3 harbored seminomatous disease leaving us with a total of 28 individuals. Patients were aged from 18 to 49 years old (mean age 27.8) and harbored nonseminomatous or mixed germ cell tumors in the testis tissue in different clinical stages.

Three (10.7\%) patients were classified as having stages I, while nineteen (67.8\%) were stages II and 6 (21.4\%) were classified as stage III. According to the ICGGGC risk group classification, 18 patients were classified as intermediate 10 patients as poor. $17.8 \%$ had a pure nonseminoma and the majority had mixed NSGCT (82.1\%); regarding primary testis tumor histological classification of these patients, 15 (65.2\% of all patients) had embryonal carcinoma (mean percentage of the tumor 30.5\%). Regarding histological features of retroperitoneal masses, the patients were divided as follows: 13 had teratoma, 13 had necrosis, 2 harbored viable germ cell tumors. These main characteristics of our sample are shown on Table 1.

All the patients were positioned supine and the operation was done with the patients under general anesthesia. The operative technique was chosen by the surgical team accordingly, with median incision in 16 (57.1\%) cases, " $S$ " incision in 10 (35.7\%) and laparoscopic approach in 2 (7.1\%) patients. One laparoscopic surgery was converted to a "S" incision.

The average operating time was 308 minutes (135 to 615 minutes). The blood loss averaged $865 \mathrm{ml}$ (100 to $2800 \mathrm{ml}$ ). The average hospital stay was 6 days (2 to 15 days). Blood transfusion was required in 6 procedures (21.4\%), with average transfusion units of 0.6 ( 0 to 5). As to the magnitude of the dissection, in 16 (57.1\%) cases a nerve-sparing technique was 
applied. There was no difference in perioperative data when comparing groups with different histology from the retroperitoneal mass (Table 2).

Table 1. Main characteristics of the studied group

\begin{tabular}{|c|c|}
\hline The demographic, clinical and pathological dat & \\
\hline Mean age & (18-49) 27.82 \\
\hline IGCCCG Risk Group & \\
\hline Intermediate & $18(64.2 \%)$ \\
\hline Poor & $10(35.7 \%)$ \\
\hline Clinical Stage & \\
\hline I & $3(10.7 \%)$ \\
\hline II & $21(75 \%)$ \\
\hline IIa & $3(10.7 \%)$ \\
\hline IIb & $7(25 \%)$ \\
\hline IIc & $9(32.1 \%)$ \\
\hline III & $6(21.4 \%)$ \\
\hline Lymphovascular Invasion (LVI) & $15(45.4 \%)$ \\
\hline Number of chemotherapy cycles before RPLND & 3,6 \\
\hline Histology of primary testis tumor & \\
\hline Nonseminoma & $17.8 \%$ \\
\hline Mixed NSGCT & $82.1 \%$ \\
\hline Embryonal Carcinoma & $15(53.5 \%)$ \\
\hline Teratoma & $11(39.2 \%)$ \\
\hline Coriocarcinoma & $4(14.2 \%)$ \\
\hline Yolk Sac Tumor & $3(10.7 \%)$ \\
\hline Endodermal Sinus & $6(21.4 \%)$ \\
\hline Histology of retroperitoneal mass & \\
\hline Necrosis & $46.4 \%$ \\
\hline Teratoma & $46.4 \%$ \\
\hline Viable Germ Cell Tumor (GCT) & $7.1 \%$ \\
\hline Yolk Sac & $3.6 \%$ \\
\hline Nonseminoma & $3.6 \%$ \\
\hline
\end{tabular}

Eleven patients (39.2\%) experienced at least one associated procedure, which consisted basically of resection of structures that were firmly adhered to the mass, such as kidneys, liver, ureter, colon among others and vessel sutures (Table 3). No patients died in the operating room or in the immediate post-operative period.

RPLND is considered a procedure with high morbidity. The fibrosis and desmoplastic reaction associated with the effect of platinum chemotherapy and the meticulous dissection required because of intrinsic anatomic relation of important structures accounts for the difficulty of PC-RPLND, including increased operative time, elevated blood loss and high rates of perioperative complications ${ }^{[14,15]}$. The introduction of both the modified-template RPLND, nerve-sparing and 
laparoscopic approaches has significantly decreased the morbidity associated with this procedure. However, these approaches have been indicated for selected low-risk patients with early stage tumors ${ }^{[6,14,15]}$.

Table 2. Operative data and comparison between groups according to histological features of retroperitoneal mass

\begin{tabular}{llllll}
\hline Variable & RPLND & Teratoma & Necrosis & Viable GCT & $\boldsymbol{p}$ \\
\hline Surgical time (min) & 308 (135 to 615) & 350.7 & 255.7 & 440 & 0.09 \\
Blood loss (ml) & 865 (100 to 2800) & 830 & 803.2 & 700 & 0.47 \\
Transfusion (units) & $0.6(0$ to 6) & 0.9 & 0.5 & 1 & 0.28 \\
Length of stay (days) & 6 (2 to 15) & 7.4 & 5.9 & 5 & 0.24 \\
\hline
\end{tabular}

Table 3. RPLND intraoperative associated procedures. Results are shown as n(\%)

\begin{tabular}{ll}
\hline Associated Procedures & $\mathbf{n}(\mathbf{\%})$ \\
\hline Organ resection & $\mathbf{8}(\mathbf{2 8 . 5 \% )}$ \\
Hepatectomy & $2(7.1 \%)$ \\
Nephrectomy & $2(7.1 \%)$ \\
Ureterectomy & $2(7.1 \%)$ \\
Gastrointestinal procedures & $\mathbf{3 ( 1 0 . 7 \% )}$ \\
Colectomy & $1(3.5 \%)$ \\
Enterectomy & 0 \\
Sutures & $2(7.1 \%)$ \\
Vascular sutures & $\mathbf{1 2}(\mathbf{4 2 . 8 \% )}$ \\
Arterial & $6(21.4 \%)$ \\
Aorta & $3(10.7 \%)$ \\
Mesenteric superior & 0 \\
Mesenteric inferior & $1(3.5 \%)$ \\
Renal & $0(0.0 \%)$ \\
Iliac common & $2(7.1 \%)$ \\
Iliac external & 0 \\
Venous & $6(21.4 \%)$ \\
Vena Cava & $2(7.1 \%)$ \\
Renal Vein & $2(7.1 \%)$ \\
Iliac vein & $2(7.1 \%)$ \\
\hline
\end{tabular}

Even though current indications for RPLND remain controversial, it is still an established treatment modality in certain situations: in low-stage disease, the surgical removal of involved retroperitoneal lymph nodes may promote cure with surgical therapy alone, thereby avoiding chemotherapy; in post chemotherapy disease, surgical removal may be therapeutic and in more complicated post chemotherapy disease such as late relapse or the removal of chemoresistant retroperitoneal cancer (desperation RPLND), 30\% to $40 \%$ of these patients with chemo-resistant metastatic cancer can be cured with surgical therapy alone ${ }^{[6]}$. At our service, this procedure is usually indicated for patients who remain with retroperitoneal masses after performing chemotherapy. Therefore it is important to assess the morbidity of this procedure in our region.

The present report demonstrates that RPLND can be safely performed by our surgical team. When compared to other series, we had a heterogeneous group of patients with different disease stages, which at first makes it difficult to compare with the literature ${ }^{[14]}$. Moreover, we had 4 cases of stage III patients, which have not been included in other series estimating perioperative morbidity ${ }^{[4,16]}$. The role of RPLND in men initially with IGCCCG poor-risk disease is not well established. Some patients have rapid disease progression and are eligible for surgery. The importance of second-line 
chemotherapy before RPLND is still not clear but studies suggest that patients who receive second-line chemotherapy before RPLND are less likely to be salvageable at subsequent relapse ${ }^{[17]}$.

A meta-analysis with over 800 cases cited in 34 articles, revealed that the mean complication rate was $15.6 \%$ (9.4 to 25.7) and the average operative duration was $204 \mathrm{~min}$. These complication rates and operative times are similar to contemporary RPLND series ${ }^{[14,18,19]}$.

As expected, we had high operative parameters such as operative time (308 min) and blood loss ( $865 \mathrm{ml})$. Furthermore, we had two unique cases with disseminated abdominal disease and extensive associated procedures to remove the mass (e.g. hemicolectomy, hepatectomy and nefrectomy) and lasted over 500 minutes (540, $615 \mathrm{~min}$ ). It has been described that these post chemotherapy procedures can be technically challenging and may require diverse technical capabilities and a commitment to a sometimes lengthy and arduous procedure ${ }^{[6,14]}$. The main limitation of this study is the small number of patients, which makes it difficult to draw definitive conclusions.

Despite the high intraoperative blood loss, our series was associated with a relatively low rate of blood transfusions (24.2\%). This is in part explained by the conservative and cautious attitude of the anesthesiology team, once there has been a strong tendency toward a restriction of blood transfusion in recent years ${ }^{[20]}$. In spite of the magnitude of the procedures, all patients had an uneventful recovery with a relatively short hospital stay and mortality rate of 0 . During a 12-month follow-up period we had only 2 cases of biochemical recurrence that were successfully controlled with second-line chemotherapy.

Recently, many series have been comparing the morbidity, safety and oncological results of open and laparoscopic approaches to RPLND with similar results ${ }^{[15,18,21]}$. Our experience is limited to open surgeries for advanced neoplasms and laparoscopy approach has been reserved for selected cases.

\section{Conclusion}

Retroperitoneal lymph node dissection is still a high morbidity procedure that requires experienced hands in order to obtain good oncologic control and low complication rates, and should be performed in Cancer Reference Centers. It should also be considered even in patients with metastatic disease with good response to chemotherapy.

\section{Competing interests}

The authors declare that they have no competing interests

\section{Authors' contributions}

Conception and design: Marcos F Dall'Oglio, Eduardo P Miranda; Acquisition of data: Alexandre Crippa, Adriano J Nesrallah; Drafting of the manuscript: Eduardo Miranda, Daniel K Abe; Analysis and interpretation of data - Alexandre Crippa, Daniel K Abe; Critical revision and important intellectual content: Marcos Dall Oglio; Supervision and final approval of the version: Miguel Srougi.

\section{References}

[1] Parkin DM, Muir CS. Cancer Incidence in Five Continents: Comparability and quality of data. IARC Sci Publ. 1992; 120(1): 45-173. PMid:1284606

[2] Wu X, Groves FD, McLaughlin CC, Jemal A, Martin J, Chen VW. Cancer incidence patterns among adolescents and young adults in the United States. Cancer Causes Control. 2005 Apr; 16(3): 309-320. PMid:15947883

http://dx.doi.org/10.1007/s10552-004-4026-0

[3] Jemal A, Bray F, Center MM, Ferlay J, Ward E, Forman D. Global cancer statistics. CA Cancer J Clin. 2011 Mar; 61(2): 69-90. PMid:21296855 http://dx.doi.org/10.3322/caac.20107

Published by Sciedu Press 
[4] Albers P, Albrecht W, Algaba F, Bokemeyer C, Cohn-Cedermark G, Fizazi K, et al. EAU guidelines on testicular cancer: 2011 update. Eur Urol. 2011 Aug; 60(12): 304-319. PMid:21632173 http://dx.doi.org/10.1016/j.eururo.2011.05.038

[5] Cordeiro BPV, Felipe CFP, Noronha CP, Ramos DN, Cabral ESC, Ferreira JMO et al. Estimate/2010 - Incidence of Cancer in Brazil. Ministério da Saúde (Internet). 2009 Dec 7(1): 98-9.

Available from: http://www.inca.gov.br/estimativa/2010/estimativa20091201.pdf

[6] Foster R, Bihrle R. Current status of retroperitoneal lymph node dissection and testicular cancer: when to operate. Cancer Control. 2002; Jul 9(4): 277-283.

[7] Dearnaley D, Huddart R, Horwich A. Regular review: Managing testicular cancer. BMJ. 2001 Jun; 322(7302): $1583-1588$. PMid:11431302 http://dx.doi.org/10.1136/bmj.322.7302.1583

[8] Brydoy M, Fossa SD, Klepp O, Bremnes RM, Wist EA, Wentzel-Larsen T, et al. Paternity and testicular function among testicular cancer survivors treated with two to four cycles of cisplatin-based chemotherapy. Eur Urol. 2010 Jul; 58(1): 134-140. PMid:20395037 http://dx.doi.org/10.1016/j.eururo.2010.03.041

[9] Spiess PE, Brown GA, Liu P, Tu SM, Tannir NM, Evans JG, et al. Recurrence pattern and proposed surveillance protocol following post-chemotherapy retroperitoneal lymph node dissection. J Urol. 2007 Jan; 177(1): 131-138. PMid:17162023 http://dx.doi.org/10.1016/j.juro.2006.08.092

[10] Simon FB. Challenging the EAU 2009 Guidelines on Testis Cancer: The Risk-Adapted Management of Stage I Nonseminomatous Germ Cell Tumours: Surveillance Yields Equal Results With Less Toxicity. Eur Urol. 2010; 9(1): 459-461.

[11] El Sayed S, Grando JP, Almeida SH, Mortati Neto N, Moreira HA. Post-chemotherapy residual mass in non-seminomatous testicular cancer. The role of retroperitoneal lymph node dissection. Int Braz J Urol. 2004 Sep; 30(5): 384-388. PMid:15610570 http://dx.doi.org/10.1590/S1677-55382004000500005

[12] Beck SD, Foster RS, Bihrle R, Einhorn LH, Donohue JP. Outcome analysis for patients with elevated serum tumor markers at postchemotherapy retroperitoneal lymph node dissection. J Clin Oncol. 2005 Sep; 23(25): 6149-6156. PMid:16135481 http://dx.doi.org/10.1200/JCO.2005.11.684

[13] Beck SD, Foster RS. Management of the post chemotherapy subcentimeter residual mass: the case for observation. World J Urol. 2009 Aug; 27(4): 485-488. PMid:19603172 http://dx.doi.org/10.1007/s00345-009-0452-7

[14] Williams SB, McDermott DW, Winston D, Bahnson E, Berry AM, Steele GS, et al. Morbidity of open retroperitoneal lymph node dissection for testicular cancer: contemporary perioperative data. BJU Int. 2010 Apr; 105(7): 918-921. PMid:19747353 http://dx.doi.org/10.1111/j.1464-410X.2009.08888.x

[15] Janetschek G, Hobisch A, Peschel R, Hittmair A, Bartsch G. Laparoscopic retroperitoneal lymph node dissection for clinical stage I nonseminomatous testicular carcinoma: long-term outcome. J Urol. 2000 Jun; 163(6): 1793-1796. http://dx.doi.org/10.1016/S0022-5347(05)67545-3

[16] Oldenburg J, Alfsen GC, Lien HH, Aass N, Waehre H, Fossa SD. Postchemotherapy retroperitoneal surgery remains necessary in patients with nonseminomatous testicular cancer and minimal residual tumor masses. J Clin Oncol. 2003 Sep; 21(17): 3310-3317. PMid:12947067 http://dx.doi.org/10.1200/JCO.2003.03.184

[17] Shayegan B, Carver BS, Stasi J, Motzer RJ, Bosl GJ, Sheinfeld J. Clinical outcome following post-chemotherapy retroperitoneal lymph node dissection in men with intermediate- and poor-risk nonseminomatous germ cell tumour. BJU Int. 2007 May; 99(5): 993-7. PMid:17437432 http://dx.doi.org/10.1111/j.1464-410X.2007.06740.x

[18] Rassweiler JJ, Frede T, Lenz E, Seemann O, Alken P. Long-term experience with laparoscopic retroperitoneal lymph node dissection in the management of low-stage testis cancer. Eur Urol. 2000 Mar; 37(3): 251-260. PMid:10720848 http://dx.doi.org/10.1159/000052352

[19] Guzzo TJ, Allaf ME. Laparoscopic retroperitoneal lymph node dissection for stage I and II nonseminomatous germ-cell tumors. Ther Adv Urol. 2009 Jun; 1(2): 107-114. PMid:21789059 http://dx.doi.org/10.1177/1756287209104830

[20] Mala T, Edwin B, Rosseland AR, Gladhaug I, Fosse E, Mathisen O. Laparoscopic liver resection: experience of 53 procedures at a single center. J Hepatobiliary Pancreat Surg. 2005; 12(4): 298-303. PMid:16133696 http://dx.doi.org/10.1007/s00534-005-0974-3

[21] Rassweiler JJ, Scheitlin W, Heidenreich A, Laguna MP, Janetschek G. Laparoscopic retroperitoneal lymph node dissection: does it still have a role in the management of clinical stage I nonseminomatous testis cancer? A European perspective. Eur Urol. 2008 Nov; 54(5): 1004-1015. PMid:18722704 http://dx.doi.org/10.1016/j.eururo.2008.08.022 